Şırnak Üniversitesi

Ilahiyat Fakültesi Dergisi

Sayı 27 Aralık 2021

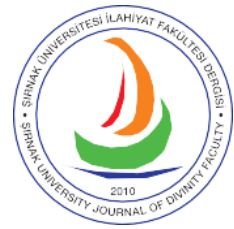

Şırnak University

Journal of Divinity Faculty

Issue 27 December 2021

e-ISSN 2667-6575

\title{
Ayahuasca: Ruhların Sarmaşığı
}

Ayahuasca: The Vine of Souls

\section{Nadide ŞAHIN}

Dr. Öğr. Üyesi, Erzincan Binali Yıldırım Üniversitesi, İlahiyat Fakültesi, Dinler Tarihi Ana Bilim Dalı Assistant Professor, Erzincan Binali Yaldirtm University, Faculty of Theology, Department of History of Religions

Erzincan / Turkey

nadide.sahin@erzincan.edu.tr

https://orcid.org/0000-0001-8986-3686

\section{Makale Bilgisi / Article Information}

Makale Türü / Article Types: Araştırma Makalesi / Research Article

Geliş Tarihi / Received: 30 Eylül / September 2021

Kabul Tarihi / Accepted: 27 Ekim / October 2021

Yayın Tarihi / Published: 15 Aralık / December 2021

Sayı / Issue: 27 Sayfa / Pages: 234-259

Atıf / Cite as: Şahin, Nadide. "Ayahuasca: Ruhların Sarmaşığı [Ayahuasca: The Vine of Souls]". Şırnak Üniversitesi İlahiyat Fakültesi Dergisi - Şırnak University Journal of Divinity Faculty 27 (December 2021), 234-259. https://doi.org/10.35415/sirnakifd.1002647

Etik Beyanı / Ethics Declaration: Bu makalede bilimsel araştırma ve yayın etiği ilkelerine riayet edilmiştir. Makale etik izin gerektirmeyen bir çalışma olup en az iki hakem tarafından incelenmiş ve intihal içermediği teyit edilmiştir./ In this article, the principles of scientific research and publication ethics are respected. The article is a study that does not require ethical permission. It has been reviewed by at least two referees and was confirmed that it did not contain plagiarism.

Copyright $@$ Published by Şırnak Üniversitesi, İlahiyat Fakültesi / Şırnak, Türkiye (Şırnak University, Faculty of Divinity, Şırnak, 73000 Turkey). 


\section{Özet}

Alg1 ve durum değişikliğine neden olan halüsinojenik bileşikler içeren psikoaktif bitkilerin binlerce yıldır yerli halklar tarafından ritüellerde kullanıldığg bilinmektedir. Bu bağlamda psikoaktif bir içecek olan ayahuasca eski zamanlardan beri Amazon ormanlarında yaşayan çok sayıda yerli kabilenin dinî, tıbbî, sosyal ve sanatsal yaşamlarında önemli bir yere sahiptir. Ayahuascayı insanın ruhsal dünyaya ilişkin algısını açmanın bir aracı olarak gören şamanlar onu büyü, kehanet, hastalıkların teşhisi ve tedavisi, avcılık vs. gibi çok çeşitli amaçlar için kullanmışlardır. Ayahuasca Amazon Ormanı'na özgü Banisteriopsis caapi ve Psychotria viridis isimli iki bitkinin karıştırılıp kaynatılmasıyla elde edilen bir özdür. Bu iki bitkinin aktif kimyasal bileşenleri arasında harmin, harmalin, tetrahidroharmin ve dimetiltriptamin (DMT) bulunur. Her iki bitki de tek başına alındığında gözle görülür bir etki oluşturmamaktadır. Bununla birlikte iki bitki saatlerce birlikte demlendiğinde bahsi geçen bileşiklerin etkileşimi sayesinde olağanüstü bir vizyoner duruma neden olmaktadır. Ayahuascanın başlıca işlevi oluşturduğu bu vizyonlar aracılığıyla diğer âlemlerle teması sağlamaktır. İçecek bu teması mümkün kılan halüsinojenik vizyonları nedeniyle Amazon grupları arasında toplu törenlerde manevî rehberlik, ruhlardan korunma, bilgi edinme ve ayrıca hastalıkları tedavi etme aracı olarak kullanılmaktadır. Yerliler bu bitkinin tesiri altında oluşan vizyonlar yoluyla önemli bilgilere erişerek kendilerine ve evrene dair hakikatleri idrak ettiklerini belirtmektedir. Bunun yanı sıra ayahuasca ritüelinin kabilenin manevî ve kültürel birikimini nesilden nesile aktaran sosyal bir ağ vazifesi de yürüttüğü görülmektedir. Bütün bu unsurları ile ayahuasca törenleri yüzyıllardır bu bölgedeki en önemli manevî ritüeli oluşturmaktadır. Ancak yerliler için ayahuasca saygıyla ve doğru koşullar altında alınması gereken çok güçlü bir içecektir, aksi takdirde gelişigüzel kullanımı aydınlatıcı olmaktan çok tehlikeli ve çoğu zaman kafa karıştırıcı bir deneyime dönüşebilir. Kullanımı muhtemelen yağmur ormanlarının sakinleri arasında ortaya çımasına rağmen, ayahuascanın bugün Brezilya başta olmak üzere Güney Amerika'daki büyük şehir merkezlerinin çoğunda ve ayrıca Amerika Birleşik Devletleri, Hollanda, İspanya, İtalya ve hatta Japonya'da kullanıldığı kaydedilmektedir. Günümüzde coğrafi ve kültürel sınırlarının çok ötesine taşınmış olan ayahuasca hakkında Batı'da pek çok eser kaleme alınmıştır ve konu çeşitli yönleriyle araştırılmaya devam etmektedir. Ülkemizde ise Dinler Tarihi alanında Amazon yerlilerinin kutsal kabul ettiği ayahuasca ile ilgili müstakil bir araştırma bulunmamaktadır. Bu çalışma ile ayahuascanın özellikleri, ayahuasca ritüelinin nasıl icra edildiği, ritüel sırasında meydana gelen vizyonlar, ritüelin Amazon havzasındaki yerliler için anlam ve önemi gibi hususları ele alarak alanımızda konu ile ilgili yapılacak olan araştırmalara katkı sağlamayı amaçlamaktayız.

Anahtar Kelimeler: Dinler Tarihi, Ayahuasca, Halüsinojenik Bitkiler, Yerliler, Şaman. 


\begin{abstract}
It is known that psychoactive plants containing hallucinogenic compounds that cause changes in perception and condition have been used in rituals by indigenous peoples for thousands of years. In this context, ayahuasca, a psychoactive beverage, has an important place in the religious, medical, social, and artistic lives of many indigenous tribes living in the Amazon forests since ancient times. Shamans, who regard ayahuasca as a means of opening people's perception of the spiritual world, used it for a wide variety of purposes such as magic, divination, diagnosis and treatment of diseases, hunting, etc. Ayahuasca is an extract obtained by mixing and boiling two plants native to the Amazon Forest, Banisteriopsis caapi and Psychotria viridis. The active chemical components of these herbs include harmine, harmaline, tetrahydroharmine and dimethyltryptamine (DMT). When either plant is ingested alone, it shows no noticeable effect. However, when the two plants are brewed together for many hours, they induce an extraordinary visionary mood. The main function of ayahuasca is to establish contact with other realms through these visions. Because of the hallucinogenic visions that make this contact possible, the drink is used among Amazonian groups in mass ceremonies as a means of spiritual guidance, protection from spirits, gaining knowledge, and also curing diseases. Indigenous people state that they comprehend the truths about themselves and the universe by accessing important information through visions formed under the influence of this plant. In addition, it is seen that the ayahuasca ritual also acts as a social network that transfers the spiritual and cultural accumulation of the tribe from generation to generation. With all these elements, ayahuasca ceremonies have been the most important spiritual ritual in this region for centuries. But Ayahuasca is a very powerful brew that ought to be taken with respect and under the right conditions for indigenous people, otherwise its haphazard use can turn into a dangerous and often confusing experience, rather than an enlightening one. Although its first use probably appeared among the inhabitants of the rainforests, ayahuasca is recorded today in most major urban centers in South America, particularly in Brazil, as well as in the United States, the Netherlands, Spain, Italy, and even Japan. Many works have been written in the West about ayahuasca, which has moved far beyond its geographical and cultural borders today, and the subject continues to be investigated from various aspects. In our country, there is no independent research on this plant, which is considered sacred by the Amazon natives, in the field of History of Religions. With this study, we aim to contribute to the research to be carried out in our field by addressing issues such as its characteristics, how the ayahuasca ritual is performed, the visions that occur during the ritual, and the meaning and importance of the ritual for the indigenous people in the Amazon basin.
\end{abstract}

Keywords: History of Religions, Ayahuasca, Hallucinogenic Plants, Natives, Shaman. 


\section{Giriş}

Ayahuasca ve diğer 'öğretmen bitkileri'nin¹ Amazon kabile toplumları tarafından kullanımı din antropolojisi alanında kozmoloji ve ritüel, Şamanizm ve trans gibi klasik antropolojik temalarla ilgilenen birçok çalışmanın konusu olmuştur. ${ }^{2}$ Özellikle 20. yüzyıl ve sonrasında Avrupa ve Amerika'da gittikçe popüler bir araştırma alanı haline gelen ayahuasca ile ilgili olarak ülkemizde Dinler Tarihi alanında yapılmış bağımsız bir çalışma yer almamaktadır. ${ }^{3}$ Bu bakımdan ele alacağımız çalışmanın alanımıza önemli bir katkı sağlamasını ummaktayız. Yapılacak çalışmalara temel olması açısından makalemizde ayahuascanın özellikleri, ayahuasca ritüeli, ritüel sırasında bu bitkinin vasıtasıyla ortaya çıkan vizyonlar ve ritüelin yerliler için anlamı ele alınacaktır.

Doğal halüsinojenler içeren bitkiler özellikle Meksika ve Güney Amerika'da yerli kabileler tarafından binlerce yıldır kullanılmaktadır. Şamanlara göre kendileriyle ruhlar arasındaki iletişimde anahtar vazifesi gören bu bitkiler insanoğluna ruhunu nasıl tanıyacağını, onu nasıl iyileştireceğini ve onunla nasıl ilişki kuracağını öğretmiştir. Bu nedenle maddî ve manevî şifa, duygusal dengeyi yeniden sağlama, negatif enerjileri uzaklaştırma, kalbi sevgiye açma vb. birçok etkisi bulunduğuna inanılan psikoaktif ${ }^{4}$ bitkiler, yerlilerce bitki dünyasının usta öğretmenleri, üstatları olarak isimlendirilirler. Ayahuascada bu usta bitki-öğretmenlerden biridir. Amazon yağmur ormanlarında yaygın olarak bulunan ve içerisinde halüsinojenik bileşikler barındıran Ayahuasca asması ruhsal ve manevî rehberlik, ruhların yardımını alma yahut ruhlardan korunma, kehanet ve büyünün yanı sıra

1 Yerliler bilgelik ve şifa elde etme vasıtası olan bitkiler için "öğretmen bitkiler" tabirini kullanmaktadır. Bk. Luis Eduardo Luna, Vegetalismo: Shamanism among the Mestizo population of the Peruvian Amazon (Stockholm: Almqvist \& Wiksell International, 1986), 64, 67- 69.

2 Gerardo Reichel Dolmatoff, Luis Eduardo Luna gibi birçok antropoloğun yanı sıra Benny Shanon, Ralph Metzner gibi psikoloji profesörü veya psikologlar, Richard Evan Schultes, Terence McKenna gibi biyologlarca yerli halkın bitkileri kullanımı, psikedelik deneyimler, Şamanizm ve bilinç, bitkinin algı üzerindeki tesirleri çerçevesinde yapılmış birçok araştırma bulunmaktadır.

3 Ayahuasca başlığı ile yapılan taramalarda karşılaştığımız iki eserden biri senarist ve yazar Yusuf Reha Alp'e ait Şamanizm Tasavouf ve Ayahuasca: Kadim Türklerin Din Anlayışı'dır. Genel itibariyle Şamanizmle ilgili başlıklar çerçevesinde şekillenmiş olan çalışmada yazar ayahuascaya Şaman ayinleri alt başlı̆̆ı içerisinde Amerika yerlilerinin uyguladığı şamanlıkta kullanılan halüsinojenik bitkiler arasında değinmiş; bir de kitabın sonunda ek kısmında Kofan yerlileri arasında bizzat deneyimlediği Ayahuasca Seremonisine dair tecrübesini aktarmıştır. Bir diğer eser ise Kübra Saatçıŏ̆lu'nun kendi ayahuasca deneyimini anlattığı Ayahuasca Yolculuğu isimli kitaptır. Bunların dışında akademisyenler tarafından yapılmış müstakil bir kitap veya makaleye rastlamış bulunmamaktayız.

4 Merkezi sinir sisteminde etki göstererek beynin işlevlerini değiştirip algı, bilinç ve davranışta geçici değişikliğe neden olan bitkileri ve maddeleri ifade eden bir terimdir. Ümit Sayın, Psikoaktif Bitkiler Psikoaktif Bitkilerin Tarihi ve Farklı Bilinç Hallerinin Psikofarmakolojisi (İstanbul: Tantra Akademi, 2016), 14. 
hastalıkları tedavi etmenin bir aracı olarak yüzyıllardır bu bölgedeki yerlilerce ritüelistik olarak tüketilmektedir. ${ }^{5}$

Ayahuascanın bölgedeki etnik gruplar arasındaki kullanımına baktığımızda öneminin birçok kabile arasında olağanüstü olduğunu görmekteyiz. Yerliler için ayahuasca bilginin ve toplumlarının kökenini ifade etmektedir. Bitkilerin anası olarak görülen ayahuasca birçok kabile için büyük bir öğretmendir. Bu usta öğretmenin eski dünyayla yani ataların dünyasıyla temasa geçmekle eşdeğer olduğu kabul edilir. Bu bakımdan ayahuasca kendisi aracılığıyla bu ve diğer dünyaların, geçmiş ve gelecekteki olayların bilgisinin elde edilebileceği etkili bir varlık olarak kabul edilir. Kendine ait bir ruhu olan ayahuasca insanın da ruhunu açar ve ona zihinsel bir güç verir. ${ }^{6}$ Ayahuascanın doğal çevreyi, coğrafyayı, bitki ve hayvan âlemlerini keşfetmeye yardımcı olduğuna da inanılır. Kişinin kendini ve evreni anlamasına yardımcı olmasının yanı sıra şamanların hastalıkları teşhis etmelerini, bu hastalıkların doğal ya da doğaüstü nedenini öğrenerek şifa bulmalarını sağlar. Şaman ve kabile üyeleri ayahuascanın yardımıyla av bulabilir, düşmanların planlarını keşfedebilir, uzak akrabalarla iletişim kurabilir, zaman ve mekândan bağımsız seyahat edebilir. Bunlara ilave olarak vücut boyamalarının yahut yerleşim yerlerinin süs tasarımlarını ve danslarını belirleyen ayahuasca hem yerli halkın mitlerini görselleştirmeye yardımcı olur hem de entelektüel becerilerinin yanı sıra sanatsal becerileri geliştirmeye katkı sağlar. ${ }^{7}$

Yukarıda söz edilen bilgiler çerçevesinde antropologlar ayahuasca kullanımını üç kategoride sinıflandırır:

- Dinî ritüeller (ata ve orman ruhları ile iletişim sayesinde ilahî rehberlik almak, koruyucu bir ruh edinmek vb.), kehanet (aileyi hangi tehlikelerin tehdit edip etmediği, düşmanların onlara karşı bir saldırı planlayıp planlamadığı, kötü büyücülerin onlara karşı hareket edip etmediği, kendi girişimlerinde başarılı olup olmayacakları gibi durumları öğrenebilme) ve hastalığa yahut başkalarının kötü

5 Ralph Metzner, "Introduction: Amazonian vine of Visions", The Ayahuasca Experience: A Sourcebook on the Sacred Vine of Spirits, ed. Ralph Metzner (Canada: Park Street Press, 2014), 1; Richard Evans Schultes, "An Overview of Hallucinogens in the Western Hemisphere", Flesh of the Gods, ed. Peter Furst (New York: Praeger Publishers, 1972), 35.

6 Michael Taussig, Shamanism, Colonialism and the Wild Man (Chicago: University of Chicago Press, 1987), 140, 265.

7 Luis Eduardo Luna, "Indigenous and Mestizo Use of Ayahuasca An Overview", The Etnopharmacology of Ayahuasca, ed. Rafael Guimaraes dos Santos (India: Transworld Research Network, 2011), 12. Luna, Vegetalismo: Shamanism among the Mestizo population of the Peruvian Amazon, 60. 
niyetine karşı önleyici bir vasıta olarak kullanabilmek için büyücülük amacıyla kullanımı

- Hastalığın nedenini belirlemek ve tedavisini sağlamak

- Üyeler ve topluluklar arası sosyal etkileşim, vecd haline ulaşmak, afrodizyak durumları etkilemek ${ }^{8}$

Ayahuascanın ana işlevi gerçekliğin görünmeyen tarafıyla temasa geçmektir. Günlük yaşamın ardındaki hakiki güçler bu görünmeyen yüzdedir. Bu güçlere de ayahuascanın sağladığı psikedelik deneyim sayesinde erişilebilir. Bu deneyimin sağladığı vecd halinin verdiği coşkunluk kutsaldır. Bu vecd hali sırasındaki değiştirilmiş bilinç durumunu bazı araştırmacılar şamanik bilinç durumu, bazıları bütünleyici bilinç terimleri ile ifade etmektedirler. ${ }^{9}$ Diğer âlemlere seyahat etmek ve ritüele katılanların gerçekliğin diğer tarafına yaptığı tehlikeli yolculuklara yardımcı olmak şamanın uzmanlık alanındadır. ${ }^{10}$ Ritüeli yürüten şaman her birinin kendi özel sesleri, ritimleri, müziği, kokuları, renkleriyle farklılık arz eden deneyimleri ile katılımcları kozmosun kendine özgü bir bölgesine götürür. Ayahuasca ritüeli ile ilgili ayrıntılı bilgilere geçmeden önce bu bitki ve onunla hazırlanan içeceğin özelliklerini ve hazırlanışını ele almak istiyoruz.

\section{Ayahuascanın Özellikleri ve Hazırlanışı}

Kaynağını Amazon havzasından alan ayahuasca Peru, Brezilya, Kolombiya ve Ekvador'daki yerli ve melez şamanlar tarafından yüzyıllardır kullanılan psikoaktif özelliklere sahip bir bitki ve bu bitki ile yapılan içeceğin adıdır. Bitkinin vizyoner özelliğini çağrıştıran isimlendirmesi iki yerli kelimeden türetilmiştir. Birincisi 'ruh', 'ata' veya 'ölü insan' anlamına gelen aya; ikincisi ise 'asma, sarmaşık' veya 'ip' anlamlarına gelen 'huasca'dır. Bu nedenle yaygın olarak 'ruhların sarmaşığı/asması' veya 'ölülerin ipi' olarak bilinmektedir. ${ }^{11}$ Sembolik olarak ruh âlemlerine tırmanılan ipe yahut sarmaşığa işaret

8 Marlene Dobkin de Rios, Visionary Vine: Hallucinogenic Healing in the Peruvian Amazon (United States of America: Waveland Press, 1984), 45.

9 Michael Harner, The Way of the Shaman: A Guide to Power and Healing (Toronto, New York: Bantam Books,1980), 59; Michael Winkelman, Shamanism: A Biopsychosocial Paradigm of Consciousness and Healing (California: Praeger, 2010), 21.

10 Harner, The Way of the Shaman: A Guide to Power and Healing, 25 - 26.

11 Laurent Rivier - Jan Erik Lindgren, “Ayahuasca The South American Hallucinogenic Drink: Ethnobotanical and Chemical Investigation", Economic Botany 26/2 (1972): 101. 101-129; Metzner, "Introduction: Amazonian vine of Visions", 1. 
etmektedir. Yerlilerce ayahuasca tabiri hem bu sarmaşık için hem de bu bitkinin de içerisinde yer aldığı karışım içecek için kullanılmaktadır. ${ }^{12}$

Ayahuasca asması yani Latince adı ile banisteriopsis caapi temel unsur olmak kaydıyla oluşturulan halüsinojenik karışımda kullanılan diğer bitkiler şaman ve şifacılara göre değişiklik arz edebilmektedir. Farklı ülkelerdeki farklı kabilelerde caapi, yage, natema ve mihi gibi yerel isimlerle de anılan bu içeceğe tüm olası karışımlarda temel unsur bahsi geçen asma olduğundan kaynaklarda kapsayıcı anlamda ayahuasca adı verilmektedir.13 Ancak bu noktada şunu ifade etmek gerekir ki az önce belirtildiği gibi banisteriopsis tabanını kullanan onlarca kombinasyon ihtimali olmasına rağmen günümüzde ayahuasca denildiğinde tipik olarak anlaşılan ve popüler olan ayahuasca asmasına (banisteriopsis caapi) chacruna (psychotria viridis) yapraklarının eklenmesiyle elde edilen içecektir. ${ }^{14}$

Ayahuasca asmasından ve chacruna bitkisinin yapraklarından yapılan içecek onu içen kişi için yaşadığı dünyanın farklı deneyimlerini açan güçlü bir halüsinojenik karışımdır. Ayahuasca asmasında harmine, harmaline, tetrahydroharmine olarak isimlendirilen beta karbolin alkaloidleri bulunmaktadır. Chacruna ise halüsinojenik alkaloid dimetiltriptamin $(\mathrm{DMT})^{15}$ içermektedir. Ancak bu madde tek başına ve ağızdan alındığında monoamin oksidazın etkisi nedeniyle yüksek dozlarda bile alınmış olsa inaktiftir. Ayahuasca asmasındaki beta karbolin alkaloidleri halüsinojenik özelliklerini göstermek için çok düşük dozajda olsalar da DMT'yi monamin oksidazın etkisinden kurtararak onun psikoaktif özelliklerini göstermesine imkân sağlar. ${ }^{16}$ Yerliler bu süreci ayahuasca asmasının 'gücü' barındırması, chacruna yaprağının da '1şı̆̆ı' getirmesi şeklinde ifade eder. Sonuçta bu iki bitkinin uygun şekilde karıştırılıp kaynatılması ile elde edilen ayahuasca çayı kan dolaşımı yoluyla beyne ulaşarak eşlik eden bir hafıza kaybı yahut bilinç kaybı olmaksızın algı, düşünce ve duygularda değişikliğe neden olur. Böylece farklı âlemlere ve varlıklara ulaştıran

12 Luna, Vegetalismo: Shamanism among the Mestizo population of the Peruvian Amazon, 16.

13 Dobkin De Rios, Visionary Vine: Hallucinogenic Healing in the Peruvian Amazon, 8; Bazı araştırmacılar arkeolojik kanıtlar çerçevesinde bu bitkinin binlerce yıldır kullanıldığını iddia etmektedir. Bk. Melanie J Miller vd., "Chemical Evidence for the Use of Multiple Psychotropic Plants in a 1,000 Year Old Ritual Bundle from South America", Proceedings of the National Academy of Sciences (PNAS) 116/23 (2019), 11207.

14 Constanza Sanchez - Jose Carlos Bouso, "Ayahuasca: From the Amazon to the Global Village" Drug Policy Briefing 43 (2015), 4.

15 Ruh molekülü olarak da bilinen dimetheltryptamine ile ilgili olarak ayrıntılı bilgi için Bk. David Luke (ed.) Rory Spowers (ed.), DMT Dialogues: Encounters with the Spirit Molecule (Vermont: Park Street Press, 2018).

16 Dennis J. McKenna, G. H. N. Towers vd., “Monoamine Oxidase Inhibitors in South American Hallucinogenic Plants: Tryptamine and beta-Carboline Constituents of Ayahuasca", Journal of Ethnopharmacology 10 (1984), 195; Sayın, Psikoaktif Bitkiler Psikoaktif Bitkilerin Tarihi ve Farklı Bilinç Hallerinin Psikofarmakolojisi, 147. 
vizyoner deneyimin tetiklenmesini sağlar. ${ }^{17}$ Psikoaktif etkilerinin yanı sıra ayahuascanın bileşenleri kusturucu, antimikrobiyal ve antihelmintik ${ }^{18}$ etkilere de sahiptir. Bu özelliği karışımın bir kusturucu ve müshil olarak organizmayı tüm kirliliklerinden arındıran bir şifa kaynağı olarak kullanımını da açıklar. ${ }^{19}$ Ayahuasca diğer bitkilerin özelliklerini öğrenebilmek için de bir araçtır. Şaman belirli bir bitkinin ne gibi etkileri olduğunu görmek isterse ayahuasca karışımını hazırladığı esnada bu bitkinin birkaç yaprağını demlemeye ekler. Bu bitkilerin özellikleri ve uygulamaları vizyonlar yoluyla aktarılır. Bu durum şamanların ayrı ayrı etki göstermeyen bu bitkilerin nasıl karıştırılması gerektiğine dair bilgilerinin kaynağı olarak gösterilir..$^{20}$

Yukarıda ifade edilen özellikleri haiz karışımın hazırlanmasında ilk olarak uzunlamasına kesilen caapi asmalarının sapları temizlenip ezildikten sonra chacruna yapraklarıyla birlikte bir kazana konulur. Üzerine su eklenen karışım bir şaman gözetiminde saatlerce kaynatılır. İki bitki bir araya geldiğinde birbirlerini tamamlar ve vücuttaki organik triptaminlerle aynı kimyasal yapıya sahip psikoaktif bir bileşik ortaya çıkar. Bu iki bitki merkezde olmak üzere yardımcı ek bitkiler de ilave edilebilir. Böylece karışım sinaptik reseptör ${ }^{21}$ bölgelerine sorunsuz bir şekilde bağlanarak güçlü bir vizyoner deneyim sağlar. Bu güçlü etkileri olan içecek sıradan bir insanın rastgele hazırlayabileceği bir karışım değildir. Karıştırılacak bitki miktarları, katılacak suyun miktarı ve ph değeri gibi özellikler, ne kadar kaynatılacağı gibi hususlar doğru ve istenen etkiyi göstermesi bakımından oldukça önemlidir.

Kaynatılarak hazırlanan öz çamurumsu keskin bir sıvıdır. Yutulduğunda, mideden yayılan bir sıcaklık hissi ile birlikte esenlik hissi ürettiği belirtilir. Ardından vizyoner etkiler başlar. Katılımcılardan farklı olarak şamanın gözünde kişinin vücudunda bulunan hastalıkların sembolleri de görülür. Görme evresi sırasında kusma veya ishal de gerçekleşebilir. Bu durum bedensel işlevlerini kontrol etmeye dayalı yetiştirilmiş yerli

17 Metzner, "Introduction: Amazonian vine of Visions", 1-2; iki bitkinin içinde yer alan halüsinojenik bileşiklerle ilgili ayrıntılı bilgi için Bk. Dennis J. McKenna vd, "The Scientific Investigation of Ayahuasca: A Review of Past and Current Research", The Heffter Review of Psychedelic Research 1 (1998), 65-76.

18 Bağırsak parazitlerinin tedavisinde kullanılan ilaçlar. Bk. Hidayet Tutun-Adnan Ayan, “Türkiye'de Antelmintik Etkili Bitkiler", Tıp Bilimlerinde Farklı Bakışlar, ed. Ali Şimşek vd. (Ankara: İksad Publishing House, 2019), 287 - 288.

19 Luna, Vegetalismo: Shamanism among the Mestizo population of the Peruvian Amazon, 57 - 59.

20 Melvin Lee Bristol, "The Psychotropic Banisteriopsis Among the Sibundoy of Colombia”, Botanical Museum Leaflets 21/5 (1966), 135- 136.

21 İç ve dış ortamlardan gelen uyarılar reseptörler vasıtasıyla alınır. Sayın, Psikoaktif Bitkiler Psikoaktif Bitkilerin Tarihi ve Farklı Bilinç Hallerinin Psikofarmakolojisi, 15 - 16. 
olmayan insanlar için duygusal olarak rahatsız edici olabilir. Ancak arınmanın fiziksel hastalığa yol açabilecek ruhsal zehirleri serbest bıraktığına inanan Amazon halkı tarafından bu durum memnuniyetle karşılanmaktadır. Yerlilere göre sistemi fiziksel ve ruhsal olarak temizleyen ayahuasca ruha manevî dengesini geri kazandırır. Ayrıca fiziksel olarak vücudu hastalıklara karşı savaşması için de güçlendirir. Yerlilerin şifalı bitkiler hakkındaki bilgileri ayahuascadan gelir. İyileştirme ritüelleri bir bitkisel ilacın uygulanmasından daha fazlasını gerektirir. Kişinin kesin olarak tanımlanmış bir dizi reçete ve yasaklara da uyması beklenir. Bitkisel reçetelerin ancak ayahuasca tarafından açıklanan bir talimat listesinin parçası oldukları sürece hastanın durumu üzerinde etkileri olduğu kabul edilir. Elde edilen tüm bu bilgiler babadan oğula geçmez. Ayahuascadan kaynaklanan bilgiler yine ayahuasca ile görülen halüsinasyonlar yoluyla iletilir. Böylece çeşitli kalıplar ortaya çıkar ve birçok şifa tarifi yaygın olarak kullanılır. ${ }^{22}$

Ayahuasca dünyevi varoluş sırasında faaliyet gösterdiği gibi doğum öncesi ve sonrası yaşama da ulaşıp etkilemektedir. Yalnız sağlıkta ve hastalıkta değil; bireyler, kabileler ve köyler arasındaki ilişkilerde, barışta, savaşta, avcılıkta, tarımda ve daha birçok hususta rol oynamaktadır. Kadınlar ayahuasca sayesinde iletişime geçtiği yüce ruhlardan çocuklarına nasıl bakacaklarının yanı sıra tarım ürünlerinin nasıl ekilip nasıl hasat edileceğini, hayvanların nasıl evcilleştirileceğini, kilden nesneler yapmayı, erkekler ise avcılık, balıkçılık, savaş tekniklerini öğrenmektedirler. Dolayısıyla kadınların ve erkeklerin görevleri için ayahuasca sayesinde güçlü ve becerikli hale gelebildiğine inanılır. ${ }^{23}$ Bunların dişında uzak yerlerde ikamet eden akrabalardan haber alabilmek yahut yolculuk halindeki bir yerlinin köyünde olan biteni öğrenebilmesi gibi amaçlarla ayahuasca alarak böylece üyelerin ruhen ailesinin/akrabalarının yanına gidebildiği belirtilmektedir. ${ }^{24}$ Dolayısıyla ayahuascanın yerli yaşamının her alanına girdiği söylenebilir. Amazon'un yerli halkının kendileri için bu kadar önem arz eden bu kombinasyonu nasıl keşfettiği ise bilinmemektedir. Nesiller boyu deneme yanılma yoluyla bunun gerçekleştiği düşünülmektedir. Yerli halk ise bunu ilahî müdahale olarak açıklamaktadır. ${ }^{25}$

22 Jacques M. Chevalier, Civilization and the Stolen Gift: Capital, Kin, and Cult in Eastern Peru (Toronto: University of Toronto Press, 1982), 344 - 346.

23 Luna, "Indigenous and Mestizo Use of Ayahuasca An Overview", 14.

24 Luna, Vegetalismo: Shamanism among the Mestizo population of the Peruvian Amazon, 60 - 61.

25 Richard Evans Schultes, "The Beta-Carboline Hallucinogens of South America", Journal of Psychoactive Drugs 14/3 (1982), 206. 
Amazon yerlilerine göre şaman, ruh dünyasının akıl almaz, zekice tasarlanmış biçimindeki bilgilerini ayahuasca etkisi altında iken gerçekleşen vizyonlar sayesinde algılar. Geometrik desenler, ritimler, koku vb. şekillerdeki bu bilgiyi insan yaşamına uyumlu kılacak şekilde çeşitli kavramlara dönüştürür. Böylece anlaşılmaz olan şeyler ayahuasca aracılığıyla şamanik bilişin uygulanabilir bir külliyatı haline gelir. ${ }^{26}$ Bir sonraki başlıkta bu şamanik külliyatın elde edildiği ayahuasca ritüelinin nasıl icra edildiğini ve yaşanan ayahuasca deneyimine atfedilen anlam ve önemi ele alacağız.

\section{Ayahuasca Ritüeli}

Halüsinojenik bitkileri içeren törensel form, bir grup insanın kullanılan psikoatif bitki vesilesiyle gerçekleşecek derin bir dönüşüm/inisiasyon ve şifa yolculuğunu paylaşmak için ruhsal/manevî tutumla bir araya geldiği deneyimlerdir. ${ }^{27}$ Şamanist toplumlarda bireyin bu ritüeller sırasında yaşadığı deneyim için metaforik olarak 'yolculuk' tabiri kullanılır. Yolculuk psikologların değişmiş bilinç durumu, antropologların ise olağandışı gerçeklik dedikleri şeydir. Bu tecrübeye sahip olanların aktardıklarına göre yolculuk, bedeni diğerleri ile birlikte yerde oturuyor iken katılımcının ruhen seyahat ettiğini ve uçabildiğini hissedebildiği, olağan deneyimlerinden çok farklı, ilginç, bazen muhteşem bazen de ürkütücü algılara kapılabildiği bir zaman aralığıdır.28

Ayahuascadan olumlu bir etki elde edilmesini sağlamak için ritüelden önce birtakım kurallar yerine getirilmelidir. Bu kurallar ayahuasca almadan birkaç gün önce baharatlı ve fermente gida içermeyen bir diyete uymak, alkolden, uyuşturucu maddelerden ve cinsel ilişkiye girmekten kaçınmaktır. ${ }^{29}$ Aksi takdirde ruhlar ortaya çıkmayabilir yahut ortaya çıkanlar kötü ruhlar olabilir. Yani törenin gerektirdiği arınma kurallarına uyulmaması korkunç vizyonlara ve hastalanmaya neden olabilir. ${ }^{30}$ Bedensel davranışları, yemek yemeyi

26 Angelika Gebhart Sayer, “Una Terapia Estetica Los Disenos Visionarios del Ayahuasca Entre los ShipiboConibo", Amazonia Indigena 46/1 (1986), 196. Ayahuasca'ya dayalı bu şamanik bilgi külliyatı ile ilgili olarak Kanadalı antropolog Jeremy Narby ilginç bir görüş öne sürmektedir. Narby'a göre ayahuasca bilincin dalga formunu şamanik görme yeteneği için görünür kılan vasıtadır. O, Amazon'daki şamanların bu karışım yoluyla "DNA temelli yaşamın evrensel ağıyla" birleşebilecekleri sonucuna varmaktadır. Ayrıntılı bilgi için bk. Jeremy Narby, The Cosmic Serpent: DNA and the Origins of Knowledge (London: Phoenix Books, 1999).

27 Av bulma, düşmanın planlarını öğrenme gibi daha özel sebeplerle yapılan şamanik uygulamalar sadece birkaç kişiyi içeren oturumlarla da gerçekleştirilebilir. Metzner, "Introduction: Amazonian vine of Visions", 13.

28 Metzner, "Amazonian Vine of Visions", 13.

29 Yiyecek alımının kontrolü, oruç tutma ve cinsel perhiz tipik arınma teknikleridir. Ayrıntılı bilgi için Bk. Mircea Eliade, Rites and Symbols of Initiation (Washington: Spring, 1998).

30 Peter Gow, Of mixed blood: Kinship and Its History in Peruvian Amazonia (Oxford: Clarendon, 1991), 238 - 239. 
ve cinsel ilişkiyi kontrol etme gereksinimi arınma eylemleri olarak kirlilikle başa çıkma yollarıdır. Bunun yanında kişi hazırlık sürecinde bu deneyime neden katılmak istediğine dair kişisel nedenlerine -manevî gelişim, şifa elde etme vb.- odaklanmalıdır. Konu ile ilgili çalışan bazı yazarlara göre ayahuasca ritüellerinin bu hazırlık yönü ahlak ve sosyal kontrol ile özel bir ilişkiye sahiptir. Bu araştırmacılar ayahuasca törenlerinin uygun davranışlar için ahlaki değerleri ve kodları ilettiğini düşünürler. Vücudun kullanımını kontrol ederek ve sınırlayarak, belirli davranış türlerinin toplum için kötü olduğu gösterilmiş olur. Böylece yerli kabilelere mensup gençler erken yaşlardan itibaren eylemlerinin hem kontrol edildiğini hem de cezalandırıldığını anlamaya başlarlar. ${ }^{31}$

Gerekli şartların yerine getirildiği hazırlık sürecinin ardından ayahuasca ritüeli ${ }^{32}$ bu halüsinojenik bitkinin kullanımında deneyimli olan bir şamanın gözetiminde gerçekleştirilir. Ritüel ormanda açık alanda veya rehberlik edecek şamanın çadırında gerçekleştirilebilir. Katılımcılar gün batımından sonra bir araya gelirler. Töreni beklerken şamanın yahut diğer tecrübeli üyelerin hikâyelerini dinleyerek zaman geçirirler. Bu sohbet esnasında şaman katılımcılara halüsinasyonlardan ne beklediklerini, neyi gerçekleştirmek istediklerini sorar ve vizyonlarda görülen renklerin, şekillerin ve ruhların mitolojik olarak ne anlama geldiğini açıklayarak bu deneyimden en iyi şekilde nasıl fayda sağlayabileceklerine dair görüşlerini paylaşır..$^{33}$ Genellikle saat 21 - 22 civarı tören başlatılır. Şaman ayahuasca karışımını alarak ikaro $^{34}$ söylemeye başlar. $^{35}$ Şamanın ikaro söylemesi ayahuascayı içeren tüm şamanik törenlerin şifa veya kehanet sürecinin başarısı için her zaman gerekli olduğu düşünülen önemli bir unsurdur. Bu ritmik ezgilerin hem psişik olarak vizyonların oluşumu ve

31 Pirjo Kristina Virtaten, "Shamanism and Indigenous Youthhood in the Brazilian Amazon", Amazonica 1/1(2009), 161.

32 Amazonda yaşayan farklı kabileler arasında ritüelde de birtakım farklılıklar görülebilmektedir. Burada ortak özellikler üzerinden tipik bir tören ele alınacaktır.

33 Gerardo Reichel Dolmatoff, The Shaman and The Jaguar A Study of Narcotic Drugs Among the Indians of Colombia (Philadelphia: Temple University Press, 1975), 164; Ross Heaven, "Plant Medicines and Shamanic Healing", Positive Health (May 2008), 12.

34 İkaro ritüeller sırasında şaman veya şifacının söylediği şarkı veya ezgilerin/melodilerin adıdır. Şifa ve bilgeliğin aleti olan ezgi, şamanın kişisel enerjisinin aracı ve gücünün sembolüdür. İkaro bir nesneyi veya iksiri şamanın gücüyle şarj etmek anlamına gelir. Böylece nesne veya iksire arınma, iyileştirme, irade üzerinde etki edebilme, koruma veya zarar verme özellikleri bahşedilmiş olur. Ayrıntılı bilgi için Bk. Dr. Rosa Giove, "The Icaro or Shamanic Song", Taxiwasi (Erişim 03 Şubat 2021).

35 Luis Eduardo Luna - Pablo Amaringo, Ayahuasca Visions: The Religious Iconography of a Peruvian Shaman (California: North Atlantic Books, 1999), 32. 
ilerlemesine destek olduğu hem de katılımcıların kötü deneyimlere takılıp kalma olasılığını en aza indirdiği düşünülür. ${ }^{36}$

Şaman söylediği ilk ikaro eşliğinde hazırlamış olduğu ayahuascayı küçük bir su kabı ile katılımcılara takdim eder. En son kendisi de karışımdan içer. Belli bir süre içeceğin etkilerini göstermeye başlaması beklenir. Erkekler ayahuascanın etkilerini beklerken genellikle tütün ürünü içerler. Tören lideri ayahuascanın ilk etkilerini hissettiğinde yanan ateşin söndürülmesini emreder. Ardından genellikle parian yapraklarından yapılan çıngırağını sallayarak karanlıkta uygun bir ikaro eşliğinde ${ }^{37}$ hem ayahuasca ruhunu hem de diğer ruhları yani vizyonları davet eder. ${ }^{38}$ Karanlık bu geleneksel törenlerin ayırt edici özelliklerindendir. Dış dünyanın görsel uyaranları yoğun olduğunda içeriden gelen görsel fenomenlere dikkat etmek zor olduğundan oluşturulan karanlık ortamın vizyonları kolaylaştırdığı belirtilir. ${ }^{39}$ Ayahuasca ile ilgili araştırmalarda bulunan Reichel Dalmotoff, Tukano kabilesinde ritüelin bu noktası ile ilgili olarak şunları kaleme almaktadır: “Halüsinasyonun birkaç aşaması vardır. İlkinde kişi sanki kuvvetli bir rüzgâr onu çekiyormuş gibi şiddetli bir hava akımı hisseder ve duyar; ritüel lideri bunun Samanyolu'na çıkış olduğunu; insanların nihai hedeflerine varmak için bu dünyadan ayrılması ve önce rüzgarlarla iletişim akımını bulmaları gerektiğini açıklar...Ve şimdi Samanyolu'nu izleyerek cennete (Ahpikondia) iniyorlar". ${ }^{40}$

Vizyonlar oluşmaya başladığında katılımcılar başlangıçta çoğunlukla parlak ışıklar, renkler ve geometrik desenler gördüklerini ifade ederler. Bunları bitkilerin veya hayvanların vb. vizyonları takip eder. Bazı durumlarda şamanın kendisi jaguar, harpy kartalı(yarı kadın yarı kuş) ve anakonda gibi büyük yırtıcı hayvanlardan birine dönüşürken bazen de bu hayvanlardan biri yahut bir öğretmen bitki antropomorfik özellikler sergileyerek katılımcılarla iletişim kurar. ${ }^{41}$

36 Metzner, "Amazonian Vine of Visions", 14.

37 Ortamda birkaç şaman olduğunda ikaroyu her biri aynı anda söyler. Birçok kişi tarafında söylenen ikaroların çok daha etkili olacağı düşünülmektedir. Bk. Luna - Amaringo, Ayahuasca Visions: The Religious Iconography of a Peruvian Shaman, 32.

38 Stephan V. Beyer, Singing to the Plants: A Guide to Mestizo Shamanismin the Upper Amazon (Ebup, University of the New Mexico Press, 2009), 16 - 19.

39 Metzner, "Amazonian Vine of Visions", 14.

40 Gerardo Reichel Dolmatoff, Amazonian Cosmos: The Sexual and Religious Symbolism of the Tukano Indians (Chicago and London: University of Chicago Press, 1971), 173.

41 Luna, "Indigenous and Mestizo Use of Ayahuasca An Overview”, 10. 
Pek çok kişi bu vizyonlarla birlikte harika ritimler duyduğunu aktarır. Yerliler bu durumu ruhların da ikaro söyleyerek gelmesi şeklinde açıklar. Şaman vizyonların gidişatını yönlendiren ikarolar söyleyerek ruh dünyası ile olan karşılaşmayı müzik aracılığıyla kontrol altında tutar. Müzik ortaya çıkan vizyonların içeriklerini şekillendirir. Şamanlar onlarca farklı ikaroyu ve bunların nasıl kullanılacağını bildikleri için ayahuasca melodilerinde uzmandırlar. Bu ikaroları da doğrudan ruhlardan veya ruhlardan öğrenmiş kimselerden öğrenmişlerdir. İkarolar genellikle kutsal içecek aracılığıyla işlev gören ayahuasca ruhu ve onun gibi ruhların etrafında şekillenmektedir. Ayrıca kabilenin değerleri ve tarihi birikimi de bu ikarolar sayesinde nesilden nesile aktarılmaktadır. Ayahuasca kullanmayan bebekler, çocuklar ve gençlerde törene katılabilir. Böylece ikarolar sayesinde kendi dillerini, değerlerini ve tarihlerini dinleme olanakları olur. Yine yerlilere göre her bitki ve hayvanın bir ikarosu vardır. Ayahuasca etkisi altındaki kişi bu ikaroyu öğrendiğinde o bitki veya hayvanın iyileştirici özelliklerini de içeren sırlarını öğrenebilir. Böylece kişi kendisine ifşa edilen sırların verdiği gücü kendi hayatında kullanabilir. Bunun yanında ayahuasca vizyonlarında görülen hayvanların bir kısmı ikaroları ile onlara yaşamı nasıl koruyacaklarını öğretirken bir kısmı da nasıl büyü yapacaklarını öğretir. ${ }^{42}$

Zaman zaman ikarolara ara verilir ve katılımcılar vizyonlara derinlemesine odaklanırlar. Törenin özellikle ilerleyen saatlerinde bilinç eşiği atlandığında ayahuasca bedenen hala grup halkasında olan kişiye ruhen otonom ve zamandan bağımsız deneyimler sunar. Kişi gözleri kapalı (en yaygın) veya açıkken görülebilen vizyonlar sırasında genellikle hareketsiz kalır. Süreç içinde kişiler sıklıkla kusma ve ishal evreleri de yaşarlar. Ayahuasca deneyimleri karışımın neden olabileceği herhangi bir sarhoşluk ve rahatsızlığa rağmen muzaffer bir his verebilir. Çünkü bir tür arınma göstergesi olarak kabul edildiğinden törene katılanlar bu arınma biçimini deneyimlemeyi tercih ederler. Bu durumu yaşayan katılımcı bulantı ve kusma durumlarının geçmesini bekleyerek yeniden vizyonlara konsantre olmaya çalışır. Çünkü ancak o zaman ayahuasca ruhunun ne öğretmesi gerektiğini keşfedebileceğine inanır. ${ }^{43}$

Şaman transında zirve noktasına ulaştığında grubun içinde şifa isteyen hastaları teker teker çağırır. Hastayı kurtarmak için onun kaybolan ruhunu takip eder. ${ }^{44}$ Bu esnada şaman

\footnotetext{
42 Virtaten, "Shamanism and Indigenous Youthhood in the Brazilian Amazon", 158 - 165.

43 Virtaten, "Shamanism and Indigenous Youthhood in the Brazilian Amazon", 160.

44 Luna - Amaringo, Ayahuasca Visions: The Religious Iconography of a Peruvian Shaman, 32.
} 
bazen kötü ruhların veya hastalığa sebep olan rakip bir şamanın güçlerinin saldırısı altında olduğunu sezebilir. İkisi arasında bir mücadele söz konusu olduğunda şaman özel bir ikaro söyleyerek ya bir jaguara, kartala vb. hayvana dönüşerek ya da hayvan ruhlarına yardım ederek kötü ruhlara karşı saldırır..$^{45}$ Burada şaman toplumunu korumak için hem şifacı hem de büyücü rolüne bürünmüş olur. ${ }^{46}$ Yine katılımcllar arasında gördüğü vizyonlar sebebiyle korkanlar olduğunda bir ikaro ile veya kişinin tepe noktasına duman üfleyerek o kişinin vizyonlarını ortadan kaldırmak da şamanın sorumluluğundadır. Vizyonlar güzel olup tören huzur içerisinde ilerlediğinde katılımcılar dans etmeye başlar. Dans sırasında bazen yerel enstrümanlar da kullanılır. Saatler sonra şafağa yaklaşırken şaman sessizliği sağlar. Ardından bazı katılımcılar uyuya kalırken bazıları gördüklerini diğerleriyle paylaşır. Bireysel deneyimler hakkında konuşma ritüelin önemli bir parçasıdır. ${ }^{47}$ Benzer deneyimlerin yaşanması katılımcılar arasında güven oluşturur. Bu paylaşımlar çoğunlukla katılımcıların insan ve doğanın tam bir kaynaşmasını, yaşamın tüm unsurları arasında mükemmel bir birliği deneyimledikleri yönündedir. ${ }^{48}$ Üstün bir şeyle olan birlik duygusu bireyin duygularını ve düşüncelerini düzenlemesini sağlar. Bu duyguya ise ayahuasca törenlerinde alınan halüsinojenik özün neden olduğu düşünülür. Campa yerlilerinin ayahuasca törenine iştirak eden antropolog Weiss ritüelin genel havasını değerlendirirken "Törenin tüm atmosferi, şaman ayahuasca etkisiyle trans halinde olmasına rağmen aşırılıktan uzak bir nezaket atmosferidir. Basit olsa da kesin bir formatı izleyen tören, bir dinsel uygulayıcının liderliğinde iyi ruhlarla saygıyla temas eden bir grup insanın görüntüsünü sunar" ifadelerine yer vermektedir. ${ }^{49}$

Törene iştirak eden katılımcılardan bazılarının -özellikle genç yerlilerin- ilk kullanımda vizyonları deneyimleyememesi söz konusu olabilir. Yerlilere göre bu durum onların vizyonlar hakkında yeterli bilgi sahibi olmayışından kaynaklanır. Bu kimselerin onu daha sık alması ve böylece ayahuascanın gerçekte ne içerdiğini yavaş yavaş öğrenmesi gerektiği düşünülür. Şaman/şamanların nezaretinde gerçekleştirilen törende bu

45 “...iblis ekipleri sarı bir jaguar ve siyah bir puma tarafından yönetilen doğaüstü teknelerle diğer insanların ruhlarını yakalar ve kurtarırlar..." Bk. Michael J. Harner, "Common Themes in South American Indian Yage Experiences", Hallucinogens and Shamanism, ed. Michael J. Harner (Oxford: Oxford University Press, 1973), 164.

46 Luna, "Indigenous and Mestizo Use of Ayahuasca An Overview”, 11.

47 Dolmatoff, The Shaman and The Jaguar A Study of Narcotic Drugs Among the Indians of Colombia, 199 - 200.

48 Luna - Amaringo, Ayahuasca Visions: The Religious Iconography of a Peruvian Shaman, 33.

49 Gerald Weiss, "Shamanism and Priesthood in the Light of the Campa Ayahuasca Ceremony", Hallucinogens and Shamanism, ed. Michael J. Harner (Oxford: Oxford University Press, 1973), 45. 
halüsinojenik içeceği tecrübe ederek vizyonlara erişme imkânına sahip olanlar dünyanın görünmez varlıklarıyla temasa geçtiklerini, fiziksel olanın ötesindeki âlemlere yolculuk yaparak ruhlarla ve ölülerle konuştuklarını, evrenin oluşumu ve anlamı ile ilgili hakikatleri içeren çeşitli vizyonlar gördüklerini anlatmaktadırlar. Çok yoğun gerçekleşen deneyimin hem korkunç hem ekstatik olduğu, kontrol edilemez olduğu ve genellikle son derece anlamlı ve şifa verici, iyileştirici olduğu belirtilmektedir. Ayahuasca almış olan insanlar genellikle 'daha iyi görmek' ya da 'her şeyi görmek' için bu kutsal içeceğin oldukça faydalı olduğunu, böylece kişinin ruhları, geçmişi ve geleceği görebileceğini ve dünya hakkında daha iyi bir vizyona sahip olunabileceğini söylerler..$^{50}$

Bireyin ruhsal veya görünmez dünya ile iletişim kurmak için varoluşun bir boyutundan diğerine geçmesi gerektiğini kabul eden yerliler için ayahuasca bu geçişi gerçekleştirmektir. Gerçekliğin diğer tarafına geçme süreci dünya çapında şamanist geleneklerde ortak bir motif olan doğum, ölüm ve diriliş açısından deneyimlenebilir. Nitekim ayahuascayı ritüelistik olarak tüketenler yalnızca doğumdan o güne kadar tüm yaşamlarına değil doğum öncesi ve ölüm sonrası durumlarına da şahit olduklarını, bu olayları dışarıdan bir gözle sırlarına vakıf olarak izlediklerini aktarmaktadır. ${ }^{51} \mathrm{Bu}$ geçiş yolculukları onlar için iki kozmik düzlemi ayıran duvarın kırılmasını yani bir nevi doğum ölüm sürecini temsil etmektedir. Yerlilerin içeceğin etkisi altındayken doğumu ve ölümü tattıklarını belirtmeleri ayahuasca içmeyi ‘her şeyin kaynağına ve kökenine bir ziyaret yahut tanrıyla temasa izin veren bir ölüm beklentisi' olarak algıladıkları şeklinde yorumlanır. ${ }^{52}$

Buraya kadar ifade edilenlerden hareketle yerlilere göre ayahuascanın bu âlemdeki olayların ardındaki hakikatleri görebilmek için diğer âlemlere ulaşma ve onların içini görme, algılama gücünü aktive ettiğini söyleyebiliriz. Neticede ayahuasca kullanımı ile oluşan bu değişmiş algi/bilinç durumu hem algılayanın niteliği ve kapasitesi hem de bedensel bir deneyim olarak algının bağlamı açısından özel bir varlık hali oluşturur. Günümüzde bu bitkiyle ilgili bilimsel araştırmalarda da ayahuascanın algı, duyu, iç uyaranlar ve düşünce

50 Virtaten, "Shamanism and Indigenous Youthhood in the Brazilian Amazon", 160 - 161.

51 Gerardo Reichel Dolmatoff, "Cosmology as Ecological Analysis: A View from the Rain Forest" Man 11/3 (1976), 307; Ayrıntılı bilgi için Bk. Gerardo Reichel Dolmatoff, Beyond The Milky Way: Hallucinatory Imagery of the Tukano Indians (Los Angles: Latin American Center Publications, 1978).

52 Dolmatoff, The Shaman and The Jaguar A Study of Narcotic Drugs Among the Indians of Colombia, 137 - 140. 
sürecinde değişikliklere neden olduğu kabul edilir. ${ }^{53}$ Fenomenolojik bir perspektiften bakıldığında ayahuasca alındığı bağlama dayalı olarak farklı psişik içeriğe erişmeye yardımcı olan değiştirilmiş bir bilinç durumuna neden olur..$^{54}$

Çeşitli kabileler arasında ayahuasca tüketimi ile ilgili araştırmalarda bulunan yazarlar yerlilerin ayahuasca töreninin kendilerine kişisel gelişim için önemli bir bilgi kaynağ sağladığını; kişinin etnik grubunun kendi değişim yörüngesini kontrol etmesi gerektiği ve kontrol edebileceği hissini uyandırdığını; toplumu veya bireysel üyelerini etkileyebilecek zaman veya mekan tarafından onlardan uzaklaştırılan şeyler, kişiler ve olaylar hakkında bilgi edinmelerini sağladığına inandıklarını aktarırlar. Onlara göre tören bitiminde vizyonları sona erip topluluğa dönen kişi gördükleri ve ruhlarla kurduğu iletişim sayesinde kendisin ne olduğunu ve olmadığını ne olmak istediğini, diğer insanlarla ve evrenle nasıl bir ilişki kurmak istediğini öğrenmiş olur. Dolayısıyla katılımcıya nasıl devam etmesi gerektiğini gösterip genel olarak geleceği öngörmesine yardımcı olan bu ritüel yaşamı ile ilgili bir şeyleri öğrenip karar vermesi noktasında ona yol göstericidir. ${ }^{55} \mathrm{Bu}$ nedenle vizyonlar sırasında ruhlarla insanlar arasındaki ilişki, içsel bilgeliği kazanmak ve kendini tanımak açısından oldukça anlamlı ve değerli görülür.

Bireysel katkılarının yanı sıra yerli gelenekte ayahuasca deneyimlerinin katılımcıları topluluğa ve kozmosa tamamlayıcı, bütünleştirici boyutta bağladığ ${ }^{56}$; böylece grup içinde veya gruplar arasında iş birliğini kolaylaştıran ortak norm, değer ve anlayışlara dayalı sosyal bir ăg üretmeye yardımcı olduğu kabul edilir. Ayahuascayı tüketsin veya tüketmesin bu

53 Ayrıntılı bilgi için Bk. Jose Carlos Bouso - Jordi Riba, "An Overview of the Literature on the Pharmacology and Neuropsychiatric Long Term Effects of Ayahuasca", The Ethnopharmacology of Ayahuasca, ed. Rafael Guimaraes dos Santos (India: Transworld Research Network, 2011), 55 - 64.

54 Bk. Benny Shanon, The Antipodes of the Mind: Charting the Phenomenology of the Ayahuasca Experience (Oxford: Oxford University Press, 2002). Hatta bunu daha ileri boyuta taşıyan yazar ve psikonot Terence McKenna günümüz insanlarında tarihi akışın bir noktasında ortaya çıkan genişletilmiş bilinç ve derin düşünce kapasitesinin doğrudan bu gibi bitkilerin yutulmasından ve onların oluşturduğu vizyoner etkilerden kaynaklandığını düşünmektedir. Ayrıntılı bilgi için Bk. Terence McKenna, Food of the Gods: The Search for the Original Tree of Knowledge, A Radical History of Plants, Drugs, and Human Evolution (London: Bantam Press, 1993).

55 Kenneth M. Kensinger, "Banisteriopsis usage among the Peruvian Cashinahua", Hallucinogens and Shamanism, ed. Michael J. Harner (London, Oxford, New York: Oxford University Press, 1973), 9-14; Gerardo Reichel Dolmatoff, The Forest Within: The World View Of The Tukano Amazonian Indians (Chiago: Council Oaks Books, 1996), 177 - 188; Pirjo Kristina Virtaten, "Shamanism and Indigenous Youthhood in the Brazilian Amazon", 160 - 165. Ayrıntılı bilgi için Bk. Pirjo Kristina Virtanen, "The Urban Manchinery Youth and Social Capital in Western Amazonian Contemporary Rituals", Anthropos 101/1 (2006), 159-167.

56 Doğumdan sonra bebeğin göbek bağı kopar ve onu annesinin plasentasından ayırır. Kamsa yerlilerine göre göre ayahuasca kişiyi tüm kozmosa bağlayan yeni bir göbek bağı gibidir. Luna, "Indigenous and Mestizo Use of Ayahuasca An Overview", 10. 
toplantıya katılan üyeler ritüel vesilesiyle kültürel birikimlerini, geleneklerini daha iyi öğrenir, anlar ve aktarır. Üyeler paylaştıkları ortak değerlerle birbirlerine kenetlenir. Aynı zamanda ayahuasca törenleri hem köyde ve kentte ayrı yaşayan hem de kentte birbirlerinden uzak olan inanırları bir araya getiren bir vesile olarak ortak kimlik inşa etme alanı sağlar; birlik ve dayanışma ruhunun geliştirilmesine imkân verir. ${ }^{57}$

Geleneksel olarak yerliler ayahuascayı bir okul olarak yani bilgi ve kültürlerinin kaynağ1 olarak görürler. ${ }^{58}$ Günümüzde yetişkinler çocuklarının bu içecekle kendileri kadar haşır neşir olmayışından endişelidir. Onlara göre çocukları okula gittikleri için okuma ve yazma becerisi gibi daha fazla bilgiyi kontrol edebilir. Ancak halüsinojenik bitkilerin kullanımıyla bağlantılı sıkı bir eğitimden artık geçmedikleri için genellikle aptal (düşünememe anlamında) olduklarını söylerler. Bu düşünce eksikliğinin kendini yakın akrabalarla mücadele içinde olmak/tartışmak, intihara teşebbüs etmek, cinsel anlamda uygunsuz bir ilgiyi sürdürmek ve geleneksel ahlaka aykırı diğer anti sosyal davranışlarda kendini gösterdiğini belirtirler. Onlar için sadece gerçekleri bilmek/bilgi edinmek yeterli değildir. Kişi ayahuascanın aracılığıyla bedeni, duyguları ve zekâyı görsel deneyimin sırrına vakıf olma/kavrama bağlamında bir araya getirerek iyi düşünmeyi öğrenmelidir. ${ }^{59}$

\section{Vizyonların Deneyimi: Ayahuasca Dünyası}

Vizyonların ana işlevi ontolojik olarak ondan üstün olmasa da en azından yaşanılan dünyadan bir şekilde ayrı âlemlerle temasa geçmektir. Ayahuasca kullanıcıları belli bir süreliğine geçici olarak başka âlemlerde kalıp dönmektedir. Bir başka deyişle içecekle kişi tamamen gerçek olduğunu hissettiği başka bir varoluş alanına aktarılmaktadır. Bu geçiş sürecinde ayahuascadan kaynaklı alg1 değişikliği/değiştirilmiş bilinç durumu yaşanmaktadır. Ayahuasca diğer algı türleri ve sinestetik etkilere de rastlanmasına rağmen özellikle onun vasıtasıyla görülen vizyonlarla ön plandadır. Deneyimleyenler bu vizyonların oldukça renkli, olağanüstü bir gerçeklik hissi ile canlı, çoğu zaman muhteşem ve fantastik bir hava sergilediğini ifade ederler. Hem açık hem kapalı gözlerle deneyimlenebilen görüntüler çoğu zaman tarif edilemez ancak gerçekten daha gerçek olarak nitelendirilmektedir. Ayrıca bireyler yalnız bu görüntülerin izleyicisi olmakla kalmaz kendilerini vizyonların sahnelerine

57 Virtaten, "Shamanism and Indigenous Youthhood in the Brazilian Amazon", 160 - 163.

58 Taussig, Shamanism, Colonialism and the Wild Man, 140.

59 Michael F. Brown, Tsewa's Gift: Magic and Meaning in an Amazonian Society (Alabama:University of Alabama Press, 2006), 49. 
dalmış bulabilirler. Kendilerini başka bir sanal gerçeklikte deneyimlemek için bu sahnelerde hareket edebilir ve diğer varlıklarla etkileşime girebilirler. Vizyonlara genellikle mesaj iletme, kesin anlamı açık seçik ifade etme, başka türlü elde edilemeyecek bilgileri aktarma ve daha yüksek bir öğrenim ve öğretim için araç olarak hizmet etme gibi nitelikler eşlik eder. ${ }^{60}$ İçeriğine ve bireyin özelliklerine bağlı olarak kişilerde korku, vecd, huzur ve sevgi duyguları oluşturabilen vizyonlar genellikle olağanüstü güzellikte sahnelerle karakterize edilir ve gerçekte görülen sanat eserlerini büyük bir ihtişamla aştığı belirtilir. ${ }^{61}$

Ritüel sırasında tecrübe edilen vizyonların içeriği oldukça çeşitlidir. ${ }^{62}$ Bu bağlamda renk sıçramaları, tekrarlayan ve figüratif olmayan öğeler, geometrik şekiller, ilkel figüratif öğeler, ışıklar (hale/nur) ve hızla akan kaleydoskopik görüntüler gibi görsel efektler en yaygın deneyimler arasındadır. Vizyonlarla ilgili kaydedilen bir diğer tema ruhun fiziksel bedenden ayrılarak sıklıkla uçuş hissiyle zaman ve mekân içinde yolculuk yapmasıdır. Yolculuğunda bireyin kişisel geçmişine ait herhangi bir sahneyi izlemesi, uzak mesafelere gitmesi vb. gibi durumlar söz konusu olabilir. ${ }^{63} \mathrm{Bu}$ tür bir deneyimle ilgili Harner kitabında Kolombiyalı bir Siona yerlisinin şu ifadelerini aktarmaktadır: “...Ama sonra yaşlı bir kadın beni büyük bir beze sarmak için geldi, göğsünden emmemi sağladı. Sonra çok uzaklara uçtum ve aniden kendimi tamamen aydınlık, çok açık bir yerde buldum. Her şey durgun, sakin ve huzurluydu. Burası bizim gibi yage (ayahuasca) halkının yaşadığı bir yerdi ama daha iyisiydi". ${ }^{64}$

Bireyin diğer insanlarla veya insan şekline bürünen ruhlarla temasa geçmesi de ayahuasca deneyiminin oluşturduğu vizyonlar içerisinde sıklıkla kaydedilen türlerden biridir. $\mathrm{Bu}$ insan, kendi geçmiş yaşamlarının reenkarnasyonu, ata ruhları veya rehber/öğretmen olarak tanımlanan başka insanlar olabilir. ${ }^{65}$ İnsanların yanı sıra bitki,

60 Benny Shannon, "The Epistemics of Ayahuasca Visions", Phenom and the Cognitive Science 9 (2010), 265 - 266.

61 Pablo Amaringo ayahuasca vizyonlarıyla ilgili oldukça zengin bir görsel içerik sunmaktadır. Bk. Pablo Amaringo vd., The Ayahuasca Visions of Pablo Amaringo (Vermont: Inner Traditions Bear and Company, 2011).

62 Jan Kounen, Visionary Ayahuasca A Manual for Therapeutic and Spiritual Journeys, Trans. Jack Cain (Canada: Park Street Press, 2015), 182; Shannon, The Antipodes of the Mind: Charting the Phenomenology of the Ayahuasca Experience 74, 91- 92. Shannon 130'dan fazla seansa katılarak, ayahuasca deneyimleyen 178 kişi ile görüşmüş ve aynı zamanda kendisi de 10 yıl içinde yüzden fazla kez bu içeceği deneyimlemiştir. Kişisel deneyimlerinin yanı sıra görüştüğü bu kişilerin de deneyimlerine dayanarak ayahuasca kullanımı ile ilgili vizyonları kategorize etmiştir. Bk. Shannon, The Antipodes of the Mind: Charting the Phenomenology of the Ayahuasca Experience, 44, 137.

63 Harner, "Common Themes in South American Indian Yage Experiences", 158 - 160; 173.

64 Harner, "Common Themes in South American Indian Yagé Experiences", 160.

65 Shannon, The Antipodes of the Mind: Charting the Phenomenology of the Ayahuasca Experience, 115 - 116. 
hayvan, yarı insan yarı hayvan, dünya dışı veya dünyadaki diğer âlemlerde -ormanın iç kesimleri, göl ve nehir dipleri vb.- yaşayan tamamen yabancı varlık formlarından herhangi biri de vizyonlarda görüldüğ̈̈ rapor edilen unsurlardandır. Bu varlıklar büyük veya küçük, yardımsever veya tehditkâr, tamamen görünür veya belirip kaybolan renkli 1şıklar halinde olabilirler. Nadiren kelimelerle, çoğunlukla ise telepatik olarak iletişim kurarlar. Bu niteliklerden herhangi biri ile görünmesi genelde o etnik grubun kültürel özelliklerine bağlıdır. Bu tür vizyonlarda yaygın olarak görülenler jaguar, yılan, akbaba, yarı insan yarı hayvan harpy kartalı, cüceler, birden fazla yüzü olan yaratıklar, periler, diğer göksel varlıklardır. ${ }^{66}$ Kullanımında deneyim sahibi oldukça kişi bu varlıklardan herhangi birine ait bireysel bir ruh ile tanışabilir yahut onlardan birine dönüşebilir. Ayahuasca toplulukları genellikle bitkiler, hayvanlar ve biyolojik yaşamın küresel olgusuna ilişkin iç görüler ve kavrayışlarla doğayla özel ve yakın bir bağ yaşarlar. ${ }^{67}$ Diğer bir içerik türüne geçmeden insan, bitki ve hayvanları içeren bir vizyon örneğine yer vermek istiyoruz:

\begin{abstract}
“Nixi pae (ayahuascanın yerel isimlerinden biri) içtik. İkaro söylemeye başlamadan önce biraz konuştuk. İçecek beni hareket ettirmeye başladı ve biraz daha içtim. Çok geçmeden her tarafım titremeye başladı. Yer sarsıldı. Rüzgâr esti ve ağaçlar sallandı... Nixi pae insanları ortaya çıkmaya başladı. Yayları ve okları vardı ve beni vurmak istediler. Korktum ama oklarının beni öldürmeyeceğini, sadece beni daha çok sarhoş edeceğini söylediler... Yılanlar, iri, parlak renkli yılanlar yerde sürünüyordu. Her tarafımı taramaya başladılar. Büyük bir dişi yılan beni yutmaya çalıştı ama ikaro söylediğim için başaramadı... Armadilloların kuyruklarıyla çaldıkları trompetleri ve ardından birçok kara kurbağasının şarkı söylediğini duydum. Dünya dönüştürüldü. Her şey aydınlandı. Bedenim değil fakat ruhum çok hızlı hareket ediyordu... Manyok ve sinirotuyla dolu bir sürü bahçe gördüm. Depolar mısırla doluydu. Fıstık rafları doluydu... Patikadan bir köye geldim. Çok fazla gürültü vardı, gülen insanların sesleri. Doğurganlık dansı Kacha'yı sergiliyorlardı. Herkes gülüyordu. Kadınların çoğu hamileydi. Mutluydum. İyi olacağımızı ve bol bol yiyeceğimizi biliyordum." 68
\end{abstract}

Ayahuasca vizyonları genellikle manevî veya ilahî bir temaya da sahip olabilir. Bu tür deneyim ilahî ya da yarı ilahî varlıkları ya da ışık vizyonlarını içerebilir. Bunlar iki tür de olabilir. İlahi olanla evren arasındaki ilişkiyi ortaya çıkaran veya ilahî olanla insanlar arasındaki karşılıklı ilişkiye odaklanan vizyonlardır. İlahî/manevî ışık vizyonları çeşitli şekillerde ortaya çıkar. İnsanların kafalarının etrafında haleler, vücutlardan yayılan auralar

66 Luna, "Indigenous and Mestizo Use of Ayahuasca An Overview", 18. Vizyonlarda görülen y1lan, jaguar, akbaba, kartal vb. ruhlarla ilgili ayrıntılı bilgi için Bk. Javier Regueiro, Ayahuasca: Soul Medicine of the Amazon Jungle (Epub, Lifestyle Entrepreneurs Press, 2016), 62 - 64.

67 Dolmatoff, The Shaman and The Jaguar A Study of Narcotic Drugs Among the Indians of Colombia,52-54.

68 Bereketli günlere dair bir kehanet vizyonudur. Bk. Kenneth M. Kensinger, "Banisteriopsis Usage Among the Peruvian Cashinahu", 10. 
ve insanların üzerinde ışık bulutları görülebilir. Nesnelerin parlak ve enerji yayıyormuş gibi görünebildiği, renklerin daha önce görülen renklerden farklı olduğu ve bu görsel deneyimin duygusal, entelektüel ve ruhsal olarak da hissedilebildiği ifade edilir. Bunun dışında ritüelde yer alan bireylerin etrafının ışıkla sarılabildiği veya ışık yayabildikleri ve bu tür deneyimlere sıklıkla mutluluk duygularının eşlik ettiği belirtilir. ${ }^{69}$ Bahsi geçen ışık vizyonlarının yanı sıra bireylerin fiziksel dünyadaki nesneleri birbirine bağlayan 1şık çizgilerini deneyimleyebildikleri de kaydedilir. Bu çizgiler tipik olarak kozmik enerjinin tezahürleri olarak görülür. Bireylerin bu 1şıkla etkileşime geçmesi mümkün olduğu gibi kendilerini de 1şığa dönüştürebilirler. ${ }^{70} \mathrm{Bu}$ türde yer alabilecek vizyonlarla ilgili olarak Shanon bazı yerlilerin güçlü, tarif edilemez bir ruhsal deneyim olarak tanımlanan bir 'yüce 1şık'la karşılaştığını; ayahuascanın Tanrı'yı görmelerine izin verdiğini söylediklerini aktarmaktadır. Harner'ın kitabında ise konu ile ilgili olarak şaman için çıraklık yapan bir adamın ayahuasca tecrübesi bağlamında “Bu durumda, Tanrı (Diosu) ile birkaç kez cennete (gökyüzüne) gider, burada bir gece geçirir ve tekrar iner" ifadelerine rastlanır. İblisler yahut cehenneme ilişkin görüntüler de bu kategoride görülebilecek vizyonlardandır. Ancak cehennemin en derinine inebilmek için çok iyi bir şaman lideri veya çok deneyimli bir ayahuasca kullanıcısı olmak gerektiği; çünkü insanın orada ne kadar kalacağını ve nasıl çıkacağını bilemeyecek kadar tehlikede olduğu vurgulanmaktadır. ${ }^{71}$

Ayahuasca vizyonları ile ilgili olarak yukarıda ifade edilen tüm içeriklerin yanı sıra gezegenler arası yolculuklar, bireylerin kendi bedenlerinin içini ve diğerlerinin bedenlerinin içini görebildiği vizyonlar, arketipleri veya matematiksel formülleri içeren vizyonlarla doğum - ölüm temalarını içeren sahneler de betimlenmektedir. Baştan sona bütün bu içerikler çeşitli etnik gruplar arasında en yaygın olarak bildirilen vizyonlardır. Bununla birlikte ayahuascada görülebilecek vizyonların prensipte sınırsız olduğu iddia edilmektedir.72

Vizyonların çeşitleriyle ilgili olarak renkler, geometrik desenler ve figüratif olmayan nesnelerin yaygın olarak başlangıçta görüldüğü aktarılır. Kaleydoskopik görüntüler, iyi dizayn edilmiş figüratif görüntüler, çeşitli insan, bitki ve hayvan ruhlarının yer aldığ

\footnotetext{
69 Shannon, The Antipodes of the Mind: Charting the Phenomenology of the Ayahuasca Experience, 130 - 131; 281 - 282.

70 Kounen, Visionary Ayahuasca A Manual for Therapeutic and Spiritual Journeys, 184 - 185; Shannon, The Antipodes of the Mind: Charting the Phenomenology of the Ayahuasca Experience, 280.

71 Harner, "Common Themes in South American Indian Yage Experiences", 159.

72 Bk. Shannon, The Antipodes of the Mind: Charting the Phenomenology of the Ayahuasca Experience, 131 - 138.
} 
katılımcının izleyici olduğu ön sahneler ayahuasca törenlerinin orta dönemi ile ilişkilendirilir. Bireyin izlemekten çıkıp sahnenin ortasında yer aldığı göksel, cennetsel

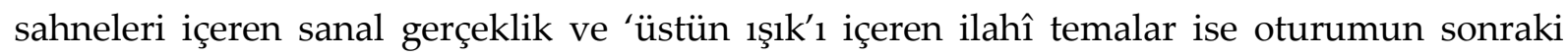
bölümlerinin karakteristiğidir. Bununla birlikte tüm vizyon türleri tüm ritüeller sırasında görülmeyebilir. Bazı bireylerin deneyimlerinde yalnız başlangıç veya orta düzeydeki vizyonlarda kalıp kişinin aktif şekilde dâhil olduğu manevî/ilahî içeriğe geçemediği de kaydedilmektedir. Karmaşık ve sofistike vizyonlar ayahuasca ile daha çok deneyim yapmış olmayı gerektirir. Genç yaşta deneyimlemeye başlayan kabile üyesi zaman içinde ilacın vizyoner gücünü nasıl kullanacağını öğrenir ve deneyim sayısı artıkça sahnede rol alma yeteneği de gelişir. ${ }^{73}$

Anlatılanlar çerçevesinde ayahuasca ritüellerinin genel olarak kendini/diğer insanları anlama, kozmik bilinç, sezgisel ve genişletilmiş bilgi, eş zamanlılık ve eş anlamlılık gibi bilişsel değişiklikler meydana getirmesinin yanı sıra evrenle bir olma, zaman ve mekânla sinırlı olmama, zihnin idrak kapasitesinin, huzur ve mutluluğun artması, kutsallık duygusu ve tarif edilemezlik gibi aşkın/mistik deneyimler de oluşturduğu görülmektedir. ${ }^{74}$ Chama yerlileri arasında ayahuasca vizyonları ile ilgili araştırmalarda bulunan Kusel bu durumla ilgili olarak şunları ifade etmektedir: "Hikâyelerinin ortak bir yanı vardır: insan, bitki ve hayvan birdir, bu birlik neden-sonuç ilişkisiyle zikzak ${ }^{75}$ deseninde birbiriyle dokunmuştur. Daha sonra ayahuasca vizyonlarının bu desenin sonsuz kombinasyonlarını gösteren kumaşlar olduğunu keşfettim". ${ }^{76}$

\section{Sonuç}

Ayahuasca günümüzde dünyanın birçok coğrafyasına yayılmış senkretik inançları ve popülaritesinin getirdiği ayahuasca inanç turizmi ile araştırılmaya açık bir alandır. Bizim dikkatimizi de bu yönüyle cezbetmiştir. Ancak alanımızda Amazon ormanlarının birçok yerli kabilesi tarafından kutsal kabul edilen ayahuasca ile ilgili geleneksel inançları içeren herhangi bir çalışma yapılmamış olması bizi öncelikle ayahuascanın özellikleri, içeceğin

73 Shannon, The Antipodes of the Mind: Charting the Phenomenology of the Ayahuasca Experience, 307.

74 Bk. Shannon, The Antipodes of the Mind: Charting the Phenomenology of the Ayahuasca Experience, 245; 251; 262 263.

75 Birbirinden ayrılmayacak şekilde girift bir dokuma kastedilmektedir.

76 Heinz Kusel, "Ayahuasca Drinkers Among the Chama Indians of the Northeast Peru", Psychedelic Review 6 (1965), 60 . 
merkezi rol oynadığı ritüeller ve sebep olduğu vizyonlarla, ayahuascanın bu bölgedeki yerli halk için anlam ve önemini araştırmaya itmiştir.

Ayahuascanın kökeni Amazon ormanlarında ikamet eden yerli kabilelere dayandırılmaktadır. Halüsinojenik bileşenler içeren bu bitki ve onunla hazırlanan güçlü psikoaktif içecek çok eski zamanlardan beri bu bölgedeki birçok kabilenin dinî ritüellerinde merkezi bir konuma ve role sahiptir. Nasıl ortaya çıktığı tam olarak bilinmemekte ve bu durum yerlilerce ilahî yardım olarak açıklanmaktadır. Ayahuasca ritüelleri kehanet, hastalığı teşhis ve şifasını bulma, büyücülük, ölü ya da diri olsun bitki, hayvan ve insan ruhlarıyla iletişim kurmak, av temini, düşmanların planlarını öğrenme, uzak akrabalardan haber alma vs. gibi sosyal hayatın her alanını ilgilendiren hususları kapsamaktadır.

Ayahuasca şamanik inisiasyon sürecince öğreten ve rehberlik eden bitkiler sınıfındandır. Amazon yerlilerince ayahuasca ilişki kurmanın mümkün olduğu güçlü bir ruha sahip akıllı bir varlıktır. Yerine getirilmesi gereken kurallara uyulduğunda kendisinden bilgi ve güç elde edilir. Bu bakımdan kutsal bir bitki olarak görülür çünkü kutsal ve aşkın boyutlara giden yolu açar. Nitekim ayahuascanın başlıca işlevi oluşturduğu vizyonlar aracılığıyla diğer âlemlerle teması sağlamaktır. Ayahuasca töreni normalde görünmez olan şeylerin (ruh dünyası) görünür hale geldiği öznelerarası bir alan yaratır. Yani yerliler için ayahuasca kullanımı insanın ruhlar dünyasını görmesini sağlayan olağanüstü bir alg1 durumuna neden olmaktadır. Yani dünyayı bu ruhların niyetiyle onların bakış açısından görmektedirler. Bu bakımdan ayahuascanın bakış açısı değişikliği anlamına geldiğini söyleyebiliriz. Ayahuasca ile kişinin bireysel kimliğinin sınırlarını aşması, başka bir kişi veya bitki, hayvan gibi bir varlığın içine girmesi; hatta kimlik dönüşümü ve metamorfoz geçirmesi deneyimleri oldukça yaygındır. Bu karışım onu tüketen kişinin, ruhların bakış açısını üstlenerek bu metamorfoz ve aşkınlıktan ders almasına izin vermektedir. Şamanlar ve onların gözetiminde içeceği deneyimleyen bireyler evrenin hakikatine dair çeşitli sırları bu bakış açısı değişikliğiyle elde ederek bunları yaşamlarını refah ve huzur içinde sürdürebilmek için kullanabileceklerine inanmaktadırlar. Bu deneyim onlar için varoluşsal sorulara cevap vermek, bireylerde ahlaki değerler oluşturmak ve kendi sosyal alanlarını belirlemek gibi hususlarda yön gösterici olmaktadır.

Ayahuasca sağlık, kişisel gelişim ve ahlaki değerlerle bağlantılı olarak etnik topluluk için bir iletişim ve etkileşim alanı da sunmaktadır. Benzer bir kozmolojide paylaşılan 
deneyimler ve inançlar yoluyla kurulan bu iletişim ve etkileşimle ortak değerler çerçevesindeki geleneksel kültürel sermaye oluşur. Ve yine bu iletişim ve etkileşim sosyal ağıyla nesilden nesile iletilerek devamlılığı sağlanır. Dolayısıyla ayahuasca ritüelinin yerli geleneklerin bir temsili olarak etnik kimliklerini güçlendirici bir unsur olduğu söylenebilir.

Günümüzde Amazon havzasının sınırlarını terk etmiş olup dünya çapında bilinen ve kullanılan bir karışım olan ayahuasca, yabancılar tarafından ruhsal aydınlanma, kendini gerçekleştirme, terapötik, tıbbî veya eğlence amaçlı kullanılmak üzere coğrafi ve kültürel sınırları hareket ettirildiğinde onunla ilişkili kullanım, niyet ve anlam da tabî̂ olarak değişmektedir. Yerli halk için ayahuasca hürmet ve gerekli koşullara riayet altında alınması gereken çok güçlü bir karışımdır, aksi takdirde gelişigüzel kullanımı aydınlatıcı olmaktan çok tehlikeli ve genellikle kafa karıştırıcı bir deneyime dönüşebilmektedir. 


\section{Kaynakça}

Amaringo, Pablo vd. The Ayahuasca Visions of Pablo Amaringo. Vermont: Inner Traditions Bear and Company, 2011.

Beyer, Stephan V. Singing to the Plants: A Guide to Mestizo Shamanismin the Upper Amazon. Ebup, University of the New Mexico Press, 2009.

Bouso, Jose Carlos - Riba, Jordi. "An Overview of the Literature on the Pharmacology and Neuropsychiatric Long Term Effects of Ayahuasca". The Ethnopharmacology of Ayahuasca. ed. Rafael Guimaraes dos Santos. 55 - 64. India: Transworld Research Network, 2011.

Bristol, Melvin Lee. "The Psychotropic Banisteriopsis Among the Sibundoy of Colombia". Botanical Museum Leaflets 21/5 (1966), 113-140.

Brown, Michael F. Tsewa's Gift: Magic and Meaning in an Amazonian Society. Alabama:University of Alabama Press, 2006.

Chevalier, Jacques M. Civilization and the Stolen Gift: Capital, Kin, and Cult in Eastern Peru. Toronto: University of Toronto Press, 1982.

Dolmatoff, Gerardo Reichel. Amazonian Cosmos: The Sexual and Religious Symbolism of the Tukano Indians. Chicago and London: University of Chicago Press, 1971.

Dolmatoff, Gerardo Reichel. Beyond The Milky Way: Hallucinatory Imagery of the Tukano Indians. Los Angles: Latin American Center Publications, 1978.

Dolmatoff, Gerardo Reichel. "Cosmology as Ecological Analysis: A View from the Rain Forest" Man 11/3 (1976), 307 - 318.

Dolmatoff, Gerardo Reichel. The Shaman and The Jaguar A Study of Narcotic Drugs Among the Indians of Colombia. Philadelphia: Temple University Press, 1975.

Dolmatoff, Gerardo Reichel. The Forest Within: The World View Of The Tukano Amazonian Indians. Chiago: Council Oaks Books, 1996.

Dobkin de Rios, Marlene. Visionary Vine: Hallucinogenic Healing in the Peruvian Amazon. United States of America: Waveland Press, 1984.

Eliade, Mircea. Rites and Symbols of Initiation. Washington: Spring, 1998.

Gebhart Sayer, Angelika. “Una Terapia Estetica Los Disenos Visionarios del Ayahuasca Entre los Shipibo-Conibo". Amazonia Indigena 46/1 (1986), 189 - 218.

Giove, Rosa. "The Icaro or Shamanic Song". Taxiwasi. Erişim 03 Şubat 2021. https://takiwasi.com/docs/arti ing/about the ikaro or shamanic song.pdf

Gow, Peter. Of mixed blood: Kinship and Its History in Peruvian Amazonia. Oxford: Clarendon, 1991.

Harner, Michael. The Way of the Shaman: A Guide to Power and Healing. Toronto, New York: Bantam Books, 1980.

Harner, Michael J. "Common Themes in South American Indian Yage Experiences". Hallucinogens and Shamanism. ed. Michael J. Harner. 155 -175. Oxford: Oxford University Press, 1973.

Heaven, Ross. "Plant Medicines and Shamanic Healing". Positive Health (2008), 9 - 12.

Kusel, Heinz. "Ayahuasca Drinkers Among the Chama Indians of the Northeast Peru". Psychedelic Review 6 (1965), 58 - 66.

Kensinger, Kenneth M. "Banisteriopsis usage among the Peruvian Cashinahua". Hallucinogens and Shamanism. ed. Michael J. Harner. 9 - 14. London, Oxford, New York: Oxford University Press, 1973. 
Kounen, Jan. Visionary Ayahuasca A Manual for Therapeutic and Spiritual Journeys. Trans. Jack Cain. Canada: Park Street Press, 2015.

Luke, David (ed.) - Spowers, Rory (ed.). DMT Dialogues: Encounters with the Spirit Molecule. Vermont: Park Street Press, 2018.

Luna, Luis Eduardo."Indigenous and Mestizo Use of Ayahuasca An Overview”. The Etnopharmacology of Ayahuasca. Ed. Rafael Guimaraes dos Santos. 1-20. India: Transworld Research Network, 2011.

Luna, Luis Eduardo. Vegetalismo: Shamanism among the Mestizo population of the Peruvian Amazon. Stockholm: Almqvist \& Wiksell International, 1986.

Luna, Luis Eduardo - Amaringo, Pablo. Ayahuasca Visions: The Religious Iconography of a Peruvian Shaman. California: North Atlantic Books, 1999.

McKenna, Dennis J. vd. "The Scientific Investigation of Ayahuasca: A Review of Past and Current Research". The Heffter Review of Psychedelic Research 1 (1998), 65 - 76.

McKenna, Dennis J. - Towers, G. H. N. vd. "Monoamine Oxidase Inhibitors in South American Hallucinogenic Plants: Tryptamine and beta-Carboline Constituents of Ayahuasca". Journal of Ethnopharmacology 10 (1984), 195-223.

McKenna, Terence. Food of the Gods: The Search for the Original Tree of Knowledge, A Radical History of Plants, Drugs, and Human Evolution. London: Bantam Press, 1993.

Metzner, Ralph. "Amazonian Vine of Visions". The Ayahuasca Experience: A Sourcebook on the Sacred Vine of Spirits. ed. Ralph Metzner. Canada: Park Street Press, 2014.

Miller, Melanie J vd. "Chemical Evidence for the Use of Multiple Psychotropic Plants in a 1,000 Year Old Ritual Bundle from South America". Proceedings of the National Academy of Sciences (PNAS) 116/23 (2019), 11207 - 11212.

Narby, Jeremy. The Cosmic Serpent: DNA and the Origins of Knowledge. London: Phoenix Books, 1999.

Regueiro, Javier. Ayahuasca: Soul Medicine of the Amazon Jungle. Epub, Lifestyle Entrepreneurs Press, 2016.

Rivier, Laurent - Lindgren, Jan Erik. "Ayahuasca The South American Hallucinogenic Drink: Ethnobotanical and Chemical Investigation". Economic Botany 26/2 (1972), 101-129.

Sanchez, Constanza - Bouso, Jose Carlos. "Ayahuasca: From the Amazon to the Global Village". Drug Policy Briefing 43 (2015), 1-23.

Sayın, Ümit. Psikoaktif Bitkiler Psikoaktif Bitkilerin Tarihi ve Farklı Bilinç Hallerinin Psikofarmakolojisi. İstanbul: Tantra Akademi, 2016.

Schultes, Richard Evans. "An Overview of Hallucinogens in the Western Hemisphere". Flesh of the Gods. Ed. Peter Furst. 3 - 54. New York: Praeger Publishers, 1972.

Schultes, Richard Evans. "The Beta-Carboline Hallucinogens of South America". Journal of Psychoactive Drugs 14/3 (1982), 205-220.

Shannon, Benny. "The Epistemics of Ayahuasca Visions". Phenom and the Cognitive Science 9 (2010), 263 - 280.

Shanon, Benny. The Antipodes of the Mind: Charting the Phenomenology of the Ayahuasca Experience. Oxford: Oxford University Press, 2002.

Taussig, Michael. Shamanism, Colonialism and the Wild Man. Chicago: University of Chicago Press, 1987.

Tutun Hidayet- Ayan Adnan. “Türkiye'de Antelmintik Etkili Bitkiler", Tıp Bilimlerinde Farklı Bakışlar. ed. Ali Şimşek vd. 285 - 314. Ankara: İksad Publishing House, 2019. 
Weiss, Gerald. "Shamanism and Priesthood in the Light of the Campa Ayahuasca Ceremony". Hallucinogens and Shamanism. ed. Michael J. Harner. 40-48. Oxford: Oxford University Press, 1973.

Virtaten, Pirjo Kristina. "Shamanism and Indigenous Youthhood in the Brazilian Amazon". Amazonica 1/1(2009), 152 - 177.

Virtanen, Pirjo Kristina. "The Urban Manchinery Youth and Social Capital in Western Amazonian Contemporary Rituals". Anthropos 101/1 (2006), 159-167.

Winkelman, Michael. Shamanism: A Biopsychosocial Paradigm of Consciousness and Healing. California: Praeger, 2010. 